\title{
Social Enterprise and Sustainable Development in the Age of Acceleration
}

\section{Geoffrey Scott}

\author{
Envigogika 14 (1) - Inspiration/ Inspirace \\ Published March 30th, 2019 / Publikováno 30. 3. 2019
}

DOI: $10.14712 / 18023061.587$

\begin{abstract}
:
Work as part of an Australian Office for Learning and Teaching senior fellowship with 3700 higher education Learning and Teaching leaders from around the world over the past three years (see FLIPCurric) has identified the critical importance of giving more careful attention to agreeing on the fitness of purpose of a higher education program before confirming the fitness for purpose of what is to be delivered or assessed. This leads us to look specifically at what outcomes we expect, at what key capabilities and competencies graduates should have to equip them to negotiate the age of acceleration (Friedman, 2016). This, in turn, has led us to argue that we need to develop graduates who are not only work ready for today but also work ready plus for an uncertain tomorrow and that it is important to give more direct focus to building social enterprise projects into the curriculum.
\end{abstract}

\section{Keywords:}

Higher education; social entrepreneurship; capable; competent; curriculum transformation; work ready plus; clearing house.

\begin{abstract}
Abstrakt
Ze zkušenosti australského Úřadu pro vzdělávání a výuku vedoucích pracovníků, která během posledních tří let pracovala s 3700 vysokoškolskými učiteli z celého světa (viz FLIPCurric), vyplývá, že je důležitější se dohodnout na celkové podobě programu vysokoškolského vzdělávání než pouze na tom, co má být vyučováno nebo hodnoceno. Tak se potom můžeme lépe zaměřit na výsledky, které konkrétně očekáváme: tj. na klíčové schopnosti a kompetence, kterými bychom měli absolventy vybavit, aby se dokázali podílet na formování společnosti ve "věku zrychlení" (Friedman, 2016). Což zase vede k poznatku, že potřebujeme vychovat absolventy, kteří jsou nejen připraveni na dnešní práci, ale také na nejistou budoucnost, a v tomto ohledu také zdůrazňujeme význam sociálního podnikání i v rámci vysokoškolského kurikula.
\end{abstract}

\section{Klíčová slova}

Vysokoškolské vzdělání; sociální podnikání; schopnosti; kompetence; transformace kurikula; príprava na povolání; připravenost na výzvy 21. století; prríklady z praxe. 


\section{Introduction}

Work as part of an Australian Office for Learning and Teaching senior fellowship with 3700 higher education Learning and Teaching leaders from around the world over the past three years (see FLIPCurric) has identified the critical importance of giving more careful attention to agreeing on the fitness of purpose of a higher education program before confirming the fitness for purpose of what is to be delivered or assessed. This leads us to look specifically at what outcomes we expect, at what key capabilities and competencies graduates should have to equip them to negotiate the age of acceleration (Friedman, 2016). This, in turn, has led us to argue that we need graduates who are not only work ready for today but also work ready plus for an uncertain tomorrow.

Work ready plus has been defined as being not only competent (able to use set professional skills and knowledge correctly under set conditions) but also being capable (having high levels of personal, interpersonal and cognitive intelligence). Being work ready plus includes being sustainability literate, change implementation savvy, inventive and entrepreneurial and clear on where one stands on the tacit assumptions driving the $21^{\text {st }}$ century agenda - assumptions like growth is equally beneficial to everyone, consumption is happiness, ICT is always the answer and globalisation is great.

Such a focus has led us to look at how best to develop graduates who are not only commercial entrepreneurs but also social entrepreneurs, people who can help us identify relevant and feasible ways to tackle the social, cultural, economic and environmental challenges now facing the world, people who are motivated by a clear, agreed moral purpose. More than $90 \%$ of the world's leaders have a degree at present. However, only a limited number of undergraduates have an opportunity to see if they are capable of inventing solutions to the 'wicked' sustainability challenges facing $21^{\text {st }}$ century societies or to learn specifically how to make a desired change work consistently and effectively in practice.

Successful social entrepreneurs (like successful leaders) are deft at listening, linking, leveraging then leading and scaling up their innovation, always in that order. They combine being motivated by a clear moral purpose to help particular social groups address the key, real world challenges they face with the possession of the distinguishing emotional and cognitive capabilities of not only the effective change leader but also the successful graduate.

One example of social entrepreneurialism comes from our work with Cambodia and the Royal University of Phnom Penh (RUPP) starting in the late 1990s. This involved being on the ground and working for a number of years with key players and the Khmer people. Doing this enabled us to jointly identify the real needs for development support in higher education and other areas and specifically where capacity building and resources would most make a difference. Then we used the Australian Youth Ambassadors for Development program to identify recent graduates who were uniquely positioned with the right capabilities and experience to match the specific needs identified to work with local Khmers to build their capacity.

This resulted in projects like helping Cambodia re map land ownership using GPS after all records had been destroyed under Pol Pot. It led to the creation of cultural tourism courses delivered by RUPP and jointly supported by the University of Technology Sydney and the University of Bologna to enable Khmers to benefit financially from the growing influx of cultural tourists to places like Angkor Wat. And it led to supplying used computers and lab equipment that were being discarded by Australian HEIs to help rebuild the RUPP infrastructure that had also been destroyed under the Khmer Rouge. 
This experience demonstrated how important it is to be situated locally and to listen first (diagnose a real local need by working with the local people), then to think creatively, responsively and laterally in order to bring together and link hitherto unthought-of resources to address the challenge(s) identified, and finally to test, enhance and leverage solutions by using pilots to learn what works best by doing it before using those involved in the pilots as mentors for scale up. This 'ready, fire, aim' approach was inspired by Francis Bacon's observation in the $16^{\text {th }}$ century that 'we rise to great heights in life by a winding staircase'. It proved to be very different from the more traditional approaches to formulating aid projects at a central location remote from the day to day world of those intended to benefit. It also proved to have sustained social impact long after the external support had ceased.

Despite the demonstrated benefit and need, much of our college and university education does not highlight, teach or assess the key capabilities identified as critical by successful early career graduates and entrepreneurs to engage in such work. As mentioned, this requires students to be specifically assisted to develop the ability to listen, link, and leverage, to foster curiosity, perseverance, and to develop the ability to remain calm when things go awry and to tolerate ambiguity. It involves helping them to learn how to work productively with diversity and uncertainty, to see the benefits of humility, to be able to put troubling situations into perspective and be clear on what really counts. It involves helping them develop the ability to hone in on the key issue in a situation, to think laterally and to 'read' (diagnose what is really going on in a particular situation) and 'match' a uniquely suitable and feasible solution.

One of the key lessons from the FLIPCurric project is that 'what is assessed is what is learnt' - if what is assessed is the ability to perform set skills in set contexts, to regurgitate what the lecturer or text says, to see knowledge as operating in individual, self-contained subject areas then this is what is learnt.

As the Nobel Prize-winning economist James Heckman states:

'Conscientiousness, perseverance, sociability and curiosity matter (but) .... are not reflected in achievement test scores'.

(see Heckman, J et al 2014)

Developing work ready plus graduates with a grounding in social not just commercial entrepreneurialism aligns with recent research on the expectations of current graduates. As Martin \& Osberg (2017) observe:

Social entrepreneurship is as vital to the progress of societies as is entrepreneurship to the progress of economies, and it merits more rigorous, serious attention than it has attracted so far.

The social entrepreneur should be understood as someone who targets an unfortunate but stable equilibrium (the status quo) that causes the neglect, marginalization, or suffering of a segment of humanity; who brings to bear on this situation his or her inspiration, direct action, creativity, courage, and fortitude; and who aims for and ultimately affects the establishment of a new stable equilibrium that secures permanent benefit for the targeted group and society at large.

The Schwab Foundation (2018) has recently identified the following characteristics of mission-driven entrepreneurship. It: 
- Achieves large scale, systemic and sustainable social change through a new invention, a different approach, a more rigorous application of known technologies or strategies, or a combination of these.

- Focuses first and foremost on the social and/or ecological value creation and tries to optimise the financial value creation.

- Innovates by finding a new product, a new service, or a new approach to a social problem.

- Continuously refines and adapts the approach in response to feedback

\section{Why Bother?}

A focus on building social enterprise competencies and capabilities into the learning programs of our higher education institutions improves employability, meets the needs of the new generation of students and directly addresses the United Nations Sustainable Development Goals.

Multiple sources are indicating that the number of people seeking meaningful work is rising. For example, Mills and Siefried (2015) note that:

- The Guardian reported that in a recent study, $44 \%$ of Britons ranked meaningful work that benefits the world, as a higher priority than a high salary when seeking a new job, and $36 \%$ said they would work harder if their employer benefited society.

- Another survey from Deloitte around the same time found that $47 \%$ of millennials say that the "purpose of business is to 'improve society/protect the environment' "-up 30 percent over the last two years.

- A 2014 study by Net Impact indicated that when polled, 83\% of MBA students said they would take a $15 \%$ pay cut "to have a job that seeks to make a social or environmental difference in the word."

The UN Sustainable Development Goals have been agreed by the 193 members of the UN and will guide funding for the next 15 years. They focus on the four interlaced pillars of social, cultural, economic and environment sustainable development:

1. Goal 1: End poverty in all its forms everywhere

2. Goal 2: End hunger, achieve food security and improved nutrition and promote sustainable agriculture

3. Goal 3: Ensure healthy lives and promote well-being for all at all ages

4. Goal 4: Ensure inclusive and equitable quality education and promote lifelong learning opportunities for all

5. Goal 5: Achieve gender equality and empower all women and girls

6. Goal 6: Ensure availability and sustainable management of water and sanitation for all

7. Goal 7: Ensure access to affordable, reliable, sustainable and modern energy for all

8. Goal 8: Promote sustained, inclusive and sustainable economic growth, full and productive employment and decent work for all

9. Goal 9: Build resilient infrastructure, promote inclusive and sustainable industrialisation and foster innovation 
10. Goal 10: Reduce inequality within and among countries

11. Goal 11: Make cities and human settlements inclusive, safe, resilient and sustainable

12. Goal 12: Ensure sustainable consumption and production patterns

13. Goal 13: Take urgent action to combat climate change and its impacts

14. Goal 14: Conserve and sustainably use the oceans, seas and marine resources for sustainable development

15. Goal 15: Protect, restore and promote sustainable use of terrestrial ecosystems, sustainably manage forests, combat desertification, and halt and reverse land degradation and halt biodiversity loss

16. Goal 16: Promote peaceful and inclusive societies for sustainable development, provide access to justice for all and build effective, accountable and inclusive institutions at all levels

17. Goal 17: Strengthen the means of implementation and revitalize the global partnership for sustainable development

In working with the Higher Education Learning and Teaching Leaders from around the world who helped build the FLIPCurric site what became very clear was that what is needed now to ensure our graduates are work ready plus is not a focus just on STEM but on STEAM (Science, Technology, Engineering, Arts and Mathematics). This is because no technological, scientific or mathematical development is value free. This recognises that what needs to be placed at the heart of any enterprise are values, promoting diversity to foster effective adaptation and creating a sustainable future in areas like those identified by the UN. There is a profound difference between change (something becoming different) and progress (change that is perceived by those involved in it as being desirable, valuable and of benefit).

This issue is explored in further detail in my chapter in the 2019 book edited by Joy Higgs and colleagues on 'Higher education for employability' (Scott, G, 2019).

\section{Defining social entrepreneurship}

It is important to develop a shared definition of 'social entrepreneurship' and to distinguish it from 'commercial entrepreneurship'.

Martin \& Osberg (2017) provide the following definition:

Entrepreneurship describes the combination of a context in which an opportunity is situated, a set of personal characteristics required to identify and pursue this opportunity, and the creation of a particular outcome...The entrepreneur doesn't try to optimize the current system with minor adjustments, but instead finds a wholly new way of approaching the problem. The entrepreneur doesn't just invent and deliver in a local context but sets up a mechanism that sees scale-up and sustainability - an entrepreneurial ecosystem.

We define social entrepreneurship as having the following three components:

(1) identifying a stable but inherently unjust equilibrium that causes the exclusion, marginalization, or suffering of a segment of humanity that lacks the financial means or political clout to achieve any transformative benefit on its own;

(2) identifying an opportunity in this unjust equilibrium, developing a social value proposition, and bringing to bear inspiration, creativity, direct action, courage, and fortitude, thereby challenging the stable state's hegemony; and 
(3) forging a new, stable equilibrium that releases trapped potential or alleviates the suffering of the targeted group, and through imitation and the creation of a stable ecosystem around the new equilibrium ensuring a better future for the targeted group and even society at large.

The New Zealand Social Innovation \& Entrepreneurship Research Centre at Massey University emphasises that:

'Social entrepreneurship relates to entrepreneurial action by organisations and individuals that creates significant social value. It engages with opportunities that create this value, embraces innovation and seeks out better ways to utilise existing resources and build new resources. Research in this domain can include ecopreneurship and green entrepreneurship; sustainability and ethical issues, in addition to not-for-profit, community, charity and philanthropic businesses that have an entrepreneurial approach.'

The British Council (2017: 10) defines social entrepreneurs as:

'... people who see something wrong with the world and then develop innovative ways to put it right. They are social change makers who are fundamentally using entrepreneurial approaches to tackle complex social problems. They are working towards a world that has a fair and equal society where the potential of all people is fully realised...They combine insight, compassion and imagination to solve social and environmental problems.'

Stratan (2017) believes that a social enterprise is distinguished by its:

a) Purpose: A social enterprise has a social and/or environmental mission as part of its core purpose. Such organizations seek for profits in order to achieve their missions.

b) Impacts: A social enterprise generates significant social and environmental benefits for communities and people, in addition to revenue.

Social innovation and sustainability are other elements that distinguish social enterprises. Social entrepreneurs develop new solutions to solve social problems or use technologies to facilitate problem solving. Moreover, every social entity must be financially sustainable.

\section{Distinguishing between commercial and social entrepreneurialism}

Mohammed Yunus (n.d.), the father of micro-credit, makes the following distinction:

Commercial entrepreneurship is about benefitting me and about profit maximisation. Social entrepreneurship is about benefitting others - such enterprises make money but no one takes it out - the profits are dedicated solely to scale up.

Different indicators of success are used for commercial compared with social entrepreneurship:

- for commercial entrepreneurship key indicators include financial gain/profit obtained from those who can afford to pay; 
- for the social entrepreneur the key indicators include demonstrable (life) benefit for those who cannot necessarily afford to pay and/or are in no position to change the status quo.

An example of this distinction is the addition of micronutrients into yoghurt for Bangladeshi children. The success indicator is how many children are now healthy not how much profit is made.

As the Cambridge Institute for Sustainability Leadership observes:

"Many policies are geared toward growing GDP without sufficient regard to the quality of the growth achieved... New metrics that integrate changes in social and natural capital alongside economic output provide a more rounded view of economic progress."

\section{Examples of social entrepreneurialism currently underway around the world}

\section{Examples from Australia}

- The NSW Department of Technical and Further Education's Outreach Program which ran for almost 40 years from the mid 1970s was an example of a scalable engagement program focused on improving the life chances of disadvantaged adults by encouraging participation in post-secondary education. Outreach took the resources of TAFE out to groups of people by providing what they wanted to learn at a time and location that suited them. At its peak Outreach involved thousands of disadvantaged adult students a year. It is a good example of social entrepreneurship in post-secondary and higher education. For further details see: Transformative Learning and Frontline Teaching (pgs 73ff).

- The new Sydney School of Entrepreneurship is a collaborative project being undertaken by all 11 NSW Universities. Its portfolio includes a focus on social entrepreneurship.

- The WSU Riverfarm initiative is a living laboratory on social, cultural, economic and environmental sustainability in a rapidly growing peri-urban area. It has been jointly created by Western Sydney University, local community groups and TAFE students as a real world resource for local school students and the community to see sustainable development in action.

- Professor Athula Ginige from Western Sydney University is using low cost mobile phones in Sri Lanka to ensure food security, minimise wasteful gluts and optimise productivity.

- The conversion of spinnifex into adhesive and latex is a collaborative project between the University of Queensland working with local Aboriginal traditional owners. The Spinnifex Project is bringing the world a unique nanomaterial created out of native spinifex grass (Triodia pungens). Commercial tests of latex reinforced with spinifex nanocellulose have already shown strong potential for ... using (it as) a renewable resource with minimal environmental impact. 
- The Social Studio School Melbourne provides pathways to employment for refugees in hospitality and fashion. Self-sustaining, it runs a shop, café, and sells clothes. It was the runner up in the Ethical Enterprise Awards 2015.

- The 2010 audit undertaken by Western Sydney University into the scale up of sustainable development in Australian Universities and the creation of the Sustain Ed Network along with the development of national L\&T standards for sustainability in HE by Bonnie McBain and colleagues have identified a wide range of other quality assured projects that link social entrepreneurship with practical action to address the UN's Sustainable Development Goals in Australia.

\section{Examples from other countries}

- There are a range of national and international networks focused on building social, cultural, economic and environmental sustainability into post-secondary and higher education using social enterprise methodologies. They include:

- Enactus which engages some 72,000 students on 1730 campuses in 37 countries around the world with social enterprise projects addressing the challenges of sustainable development;

- The Association for the Advancement of Sustainability (AASHE) in the USA and the Copernicus Network in Europe;

- The United Nations University-supported network of more than 160 Regional Centres of Expertise in Education for Sustainable Development around the world;

- SENSCOT which links and leverages Scotland's social enterprises in areas ranging from community food, culture and employment support to health, sport and accessible tourism;

- Canadian province-wide initiatives like Social Enterprise Ontario which integrates the province's centre for social innovation, its social innovation pitch competition, its young social entrepreneur initiative and the Ontario social enterprise directory.

- The Institute for Social Entrepreneurship in Asia (ISEA) which is a learning and action network set up by social enterprises and social enterprise resource institutions to catalyse knowledge creation, capacity development and movement-building for social entrepreneurship in the region.

- In the 1990s The Foskor development trust in South Africa supported local, start up enterprises in the townships by providing training on small business operation and loans for township residents who came up with a feasible and innovative local business idea. The default rate on the loans was only $4 \%$. The successful small business people were then brought into the local schools to tell the students how they did it and to encourage them into their own social enterprises.

- The Blue Economy project is a world wide initiative focused on making money out of waste and creating employment and better lives for the poor. Typical Blue Economy projects include:

- In the Pacific Islands, rather than waste the faeces of pigs in a piggery, it is washed into a series of ponds on the side of a hill using a solar pump where 
algae are grown on the nutrient rich water. Fish feed on the algae, are killed, dried and then fed to the pigs. In another initiative village children gather in the feral African snails and are paid for their work. The snails, whose shells have the ideal grit composition for poultry and are highly nutritious, are fed to chickens, thereby simultaneously removing a feral pest and saving on the financial and carbon costs of importing chicken feed.

- A citrus farm in a black township in South Africa was not succeeding. When the cross-disciplinary Blue economy team was asked to help they jointly came up with a strategy that made the farm financially viable, created increased employment and made money out of waste. Once underway not only were orange juice, firewood from plantation offcuts, and mushrooms grown on the leaf litter from the plantation sold to local game lodges in the adjacent game park. But the left-over orange peels were also used to produce limonene (a natural detergent oil) and then what was left of the peels was fed to the cattle as an ideal cleansing agent for their first gut.

- In Benin maggots are grown on abattoir bones then bled for their valuable natural antibiotic before being fed to fish as a local source of protein or to quails whose eggs are sold for a high price in Europe.

- The rubbish waste pickers in Delhi make artifacts for tourists from filament produced from the plastic they collect in the dumps using solar 3D printers (see: https://www.youtube.com/watch?v=Ieqahv YQOI). This earns the waste pickers 15 times more than just selling the plastic they collect to recycling depots.

- BlueCity is an incubator for circular entrepreneurs in Rotterdam. It is focused on inventions tied to the idea of building a circular economy which aims to reuse waste and discarded objects in imaginative and profitable ways.

For a quick summary of other impressive Blue Economy Projects that adopt a social enterprise approach see Blue Economy FAQ.

- Circular Economy initiatives include the use of cradle to cradle design as a financially viable alternative to economies and businesses based on waste making. Social entrepreneurs and associated invention courses in colleges and universities are seen as being the key to achieving an expansion in the circular economy.

One example is circular fashion. The fast fashion industry is creating millions of tons of cheap clothing that goes to land fill each year. In Australia alone more than 500,000 tons of discarded clothing is reported as going to landfill each year. Hannah Cole (2018) in Fashion Journal identifies an alternative approach: circular fashion....' At its heart, circular fashion is the continual use of pieces or an earth-to-earth approach to design'. She notes that:

- Extending the life of a garment by an extra nine months reduces its environmental impact by $20-30 \%$.

- Providing one tonne of clothing for direct re-use by giving it to a charity shop or selling it online can result in a net greenhouse gas saving of 11 tonnes of carbon dioxide equivalent. 
- Giving focus to biomimicry provides another avenue for entrepreneurship in higher education. This involves using nature as a living R\&D lab. Biomimicry is based on inventions inspired by nature. Examples include:

- Velcro - based on burdock burrs;

- The ridges on humpback fins being used as a model for improving the efficiency of wind turbines by $20 \%$;

- Understanding how fireflies work being used to improve the brightness of LEDs by $55 \%$;

- Creating cement by sequestering carbon in the same way that reefs do;

- Creating permanent colours using how butterflies do it using structural colouration.

The Biomimicry Institute website gives many more examples.

- Muhammad Yunus, founder of the Grameen Bank and father of microcredit has shown how local entrepreneurship can be fostered in impoverished communities around the world.

- Victoria Hale through the Institute for One World Health by-passes the big drug companies to create drugs that serve the poor.

- Sanduk Ruitt makes cheap intraocular lenses to cure cataracts in Nepal.

Traditional cataract operations used to take many hours, were costly and, even when successful, required the patient to stay in hospital for 10 days and to wear very strong glasses for life. With the support of his mentor Fred Hollows, Ruit, a Nepali, introduced a microscope-based operation that uses two small incisions that don't require stitches (just a small entry and exit point) for the removal of the damaged lens and the insertion of an intraocular lens. This takes 5 minutes with the patient being able to go home almost immediately.

Ruit set up a factory to make the lenses and create employment in Kathmandu. The western manufacturers of intraocular lenses were charging up to $\$ 150$, while Ruit's lenses cost $\$ 3.50$. Ruit had the opportunity to become very rich in Australia but instead chose to go back to Nepal (he was born in a village at 11,000 feet under the $3^{\text {rd }}$ highest mountain in Nepal) to set up outreach clinics all over remote Nepal that charge blind Nepalis in remote villages little or nothing to restore their sight.

- (At the Nov 2017 World Social Enterprise Forum in Christchurch, New Zealand)... London-based Rob Wilson championed his "delicious and pint-sized" response to the 900,000 tonnes of fresh bread, Toast Ale - more than $40 \%$ of the total baked ... that goes into landfills each year in the UK... He has published his recipe so bakers and brewers around the world can partner up to replace expensive grain with surplus bread.

- A wide range of social enterprises are underway in New Zealand, many of which were highlighted at The 2017 World Social Enterprise Conference in Christchurch. They include restaurants run by refugee cooks; Patu Aotearoa which has developed fitness and health programs for Māori and Pacific people; the invention by Medicine Mondiale of a cheap and reliable infant incubator for use in disadvantaged 
communities; the development of a solid bar hair shampoo to remove from the waste stream the plastic bottles used to carry liquid shampoos; the conversion of green waste from restaurants into compost that is used to grow vegetables that are sold back to the restaurants; initiatives that create viable employment for people with disabilities; sending usable medical equipment and consumables that are being discarded - such as prosthetics, gloves and hospital beds - to hospitals in the Asia Pacific region.

- 'The British Council report Social Enterprise in a Global Context: the role of Higher Education Institutions engaged with more than 200 bodies in 12 countries. It found that 75 per cent of the institutions surveyed are actively involved with at least one social enterprise and over half of these are also engaged in an international social enterprise partnership'. (British Council 2017: 10).

\section{Building social enterprise into the curriculum}

Many degrees, majors, subjects and certificates on social entrepreneurship and biomimicry are provided now by tertiary education institutions around the world.

One development with great potential involves the use of a capstone on social enterprise. In the capstone a cross-disciplinary team of students is linked up with a community group, agency, business or school to jointly develop a practical solution to a real social, cultural, economic or environmental need which delivers demonstrable benefit and which becomes self-funding. As any substantial social enterprise capstone project will rarely be fully implemented in just one semester a key aspect of the capstone is to ensure that the group of students just completing their semester's work on the project efficiently and effectively hands over the project to a subsequent group with part of the assessment of the capstone involving how effective this hand-over was. Other key aspects of assessment include how effectively the students operated as a team, the feedback from clients on the benefits so far and evidenced-based self-reflection on how the key capabilities and competencies identified in studies of successful graduates in 10 professions have been progressed by participation in the capstone (see Section 3.2 of the Getting Started Section of the FLIPCurric site at: http://flipcurric.edu.au/about-143/about/using-the-guide-andgetting-started).

Many of the exemplar projects outlined above were developed by higher education students working in just this way. An ideal strategy to foster and scale up the use of social enterprise capstones is to link up with the 163 UN Regional Centres of Expertise in Education for Sustainable Development currently operating around the world as these bring together a wide range of groups in a region working on the same UN Sustainable Development Goal(s).

It is essential when a social enterprise capstone project is being evaluated that not only the capacity of the team to work productively is assessed but also that there is evidence of a demonstrably positive impact on those intended to benefit. It is to this issue that we now turn.

\section{Judging the success of a social enterprise}

As 'social benefit' is a value-laden concept it is important to agree on what indicators will be used to confirm that that a social enterprise project is a 'success'. Options include: 
- Positive inputs and participation rates

- Growth in the numbers participating in any project;

- New legislation and funding that directly supports/funds social enterprises;

- Demonstrable use of 'cradle to cradle' design and the approaches of the circular economy;

- Successful access to further education;

- Improved participation of disadvantaged groups in employment and/or education;

- Demonstrable success in scaling up the innovation/enterprise;

Increased rates of ethical investment;

- Positive feedback

- Positive feedback on satisfaction surveys from those involved in a social enterprise;

- Positive feedback from employers, community support agencies and other professional groups;

- $\quad$ Positive impact

- Making money out of waste;

- Positive health outcomes (both physical and mental) for those intended to benefit;

- Minimum default on micro-finance loans;

- More equitable distribution of wealth;

- Increased success by students traditionally under-represented in further education

- Evidence of an improvement in 'gross domestic happiness' (defined by Bhutan as 'positive' performance in the following domains: psychological wellbeing, health, time use, education, cultural diversity and resilience, good governance, community vitality, ecological diversity and resilience, and living standards);

- Improved levels of social harmony and decreased levels of civil disturbance, crime and violence;

- An observably positive change in practice, in 'how we do things around here';

- Improved housing;

- Improved ease of mobility at low cost;

- Conservation of the natural environment; 
Demonstrable decreases in pollution;

- New socially beneficial products or services that have a sustained market/usage rate;

- Increased social and cultural 'wealth';

- Repeat business;

- Positive press coverage;

- Profitability/a positive rate of return on investment

\section{Exploring the potential to develop a national searchable clearing house of successful approaches}

In order to avoid educators having to 'reinvent the wheel' there is great potential to gather in exemplars of successful ways in which social enterprise for sustainable development is being built into the curriculum of each country's colleges and universities. Fostering a nation-wide strategy is a good example of how collaborative work can be used to foster a competitive edge.

The searchable assessment database on the FLIPCurric site, although it has a different focus, is one example of how a finished product might look and operate.

\section{Conclusion}

Now is the time for us to work together to develop graduates and our future leaders who are not only work ready for today but who are also work ready plus for an uncertain tomorrow. This discussion paper has argued that, in doing this, it will be necessary to give more direct focus to building social entrepreneurship projects into the curriculum of our colleges and universities.

The existing range of networks focused on education for sustainable development provide an ideal mechanism for this to be undertaken efficiently, collaboratively and effectively.

The UN Sustainable Development Goals won't just be achieved by themselves. People must be assisted to invent relevant and feasible ways to address them and to learn how to action them. Because all change is learning, colleges and universities have a central role in this process.

Geoffrey Scott, Emeritus Professor of Higher Education \& Sustainability, Western Sydney University 


\section{References \& Further Reading}

- Blessinger, P, Sengupta, E and Makhanya, M (2018): 'Higher education's key role in sustainable development', University World News, Issue 519, 8 September 2018.

- Blundell, Sally (2017): Rise of Social Enterprise in NZ: Case studies, New Zealand Listener, At: https://www.noted.co.nz/money/business/the-rise-of-the-socialenterprise/

- British Council (2017): Social entrepreneurship in education: empowering the next generation, British Council,

At:https://www.britishcouncil.org/sites/default/files/british_council_social_entrepre neurship_in_education_web_final.pdf

- British Council (2017): New Zealand Minister hugely supportive of social enterprise, British Council, Manchester M1 6BB. At:

https://www.britishcouncil.org/society/social-enterprise/news-events/newzealand-minister-hugely-supportive-social-enterprise

- Cole, Hannah (2018 Maybe we need to take a step back and adjust the way we consume. Fashion Journal, At: https://fashionjournal.com.au/fashion/is-circularfashion-the-real-deal/

- Findlay, L (2016): Students are choosing social enterprise - businesses with a heart, Universities UK at: https://www.universitiesuk.ac.uk/blog/Pages/studentsare-choosing-social-enterprise-business-with-a-heart.aspx

- $\quad$ Friedman, T. L. (2016). Thank you for being late: An optimist's guide to thriving in the age of accelerations. New York, NY: Farrar, Straus \& Giroux.

- Fullan, M \& Scott, G (2009): Turnaround leadership for higher education, Jossey Bass, San Francisco.

- Heckman, J et al 2014: The myth of achievement tests: The GED and the role of character in American Life, University of Chicago Press, Chicago

- Higgs, J, Crisp, G \& Letts, W (forthcoming): Education for employability: learning for future possibilities, Brill, John Bennett, Boston.

- Massey University: NZ Social Innovation \& Entrepreneurship Research Centre, At: http://sierc.massey.ac.nz/

- Martin, R \& Osberg, S (2007): 'Social Entrepreneurship: The Case for Definition', Stanford Social Innovation Review At:

https://ssir.org/articles/entry/social_entrepreneurship the case for definition

- McInerney, Anne-Maree (2016): 'Ethical investment, social enterprise and The Blue Economy', In Business and Environment, Ethical Investing and Social Enterprise, November 25, 2016

- Mills, Rebecca and Siegfried, Alina (2015), Mission driven entrepreneurship: new frontiers of impact entrepreneurship, Edmund Hillary Fellowship, At:

https://stories.ehf.org/the-new-frontiers-of-impact-entrepreneurship-cc6cbce64f0c 
- New Zealand Herald (2012): Social Entrepreneurship in New Zealand: Solution to Old problems, At:

https://www.nzherald.co.nz/business/news/article.cfm?c id=3\&objectid=1084876 $\underline{8}$

- New Zealand Story Group, (2017): The Rise of Social Enterprise in New Zealand, nzte.govt.nz At: https://www.nzstory.govt.nz/blog/the-rise-of-social-enterprise-innew-zealand/

- Nordic Council of Ministers (2015): Social entrepreneurship and innovation: initiatives to promote social entrepreneurship and innovation in the Nordic countries, NCM, Copenhagen.

- Schwab Foundation (2018): What is social entrepeneurship? Schwab Foundation in partnership with the World Economic Forum. At:

https://www.schwabfound.org/what-is-social-entrepreneurship

- Scott, G, Tilbury, D, Sharp, L \& Deane, E (2012): Turnaround leadership for sustainability in higher education, Office for Learning \& Teaching, Australian Government, Sydney. At:

http://www.uws.edu.au/ data/assets/pdf file/0018/411075/TLSHE Final Exec S ummary HA 12 Nov 12 pdf version.pdf

- Scott, G (2016): Making it Happen, in Scott, G (P2016): FLIPCurric, Australian Government, Canberra, At: http://flipcurric.edu.au/make-it-happen

- Scott, G (2016): Transforming graduate capabilities and achievement standards for a sustainable future, Key insights from an Australian National Senior Teaching Fellowship. Office for Learning \& Teaching, Australian Government Canberra. At: http://flipcurric.edu.au/sites/flipcurric/media/107.pdf

- Scott, G (forthcoming): 'Preparing work ready plus graduates for an uncertain future' In Higgs, J, Crisp, G and Letts, W (2019): 'Education for Employability: learning for future possibilities', Brill, Leiden, Boston \& Singapore.

- Siegle, L (2017):_Fashion must fight the scourge of dumped clothing clogging landfills, The Guardian, 30 July 2017. At:

https://www.theguardian.com/fashion/2017/jul/29/fashion-must-fight-scourgedumped-clothing-landfill

- Social Enterprise Word Forum (2017): 2017 Final Report, SEWF, Christchurch, New Zealand. At: https://www.sewf2017.org/images/docs/SEWF-2017-Final-Report.pdf

- Social Enterprise Auckland (N.D.): Little Island Press. At: https://socialenterpriseauckland.org.nz/article/little-island-press/

- Stratan, D (2017): 'Success factors of sustainable social enterprises through a circular economy perspective', Visegard Journal of Bioeconomy and sustainable development, 1, 2017

- The Spin Off (2017): A guide to the top social enterprises in New Zealand right now, At: https://thespinoff.co.nz/business/05-10-2017/a-guide-to-the-top-socialenterprises-in-nz-right-now/ 
- United Nations University (2018): The Blue Economy Innovations, Gunther Pauli \& UNU at: https://www.theblueeconomy.org/cases-1-to-100.html

- Yunus, Mohammed (n.d.) The social business model. At:

https://www.youtube.com/watch?v=0C3XQ3BTd40 